\title{
norden
}

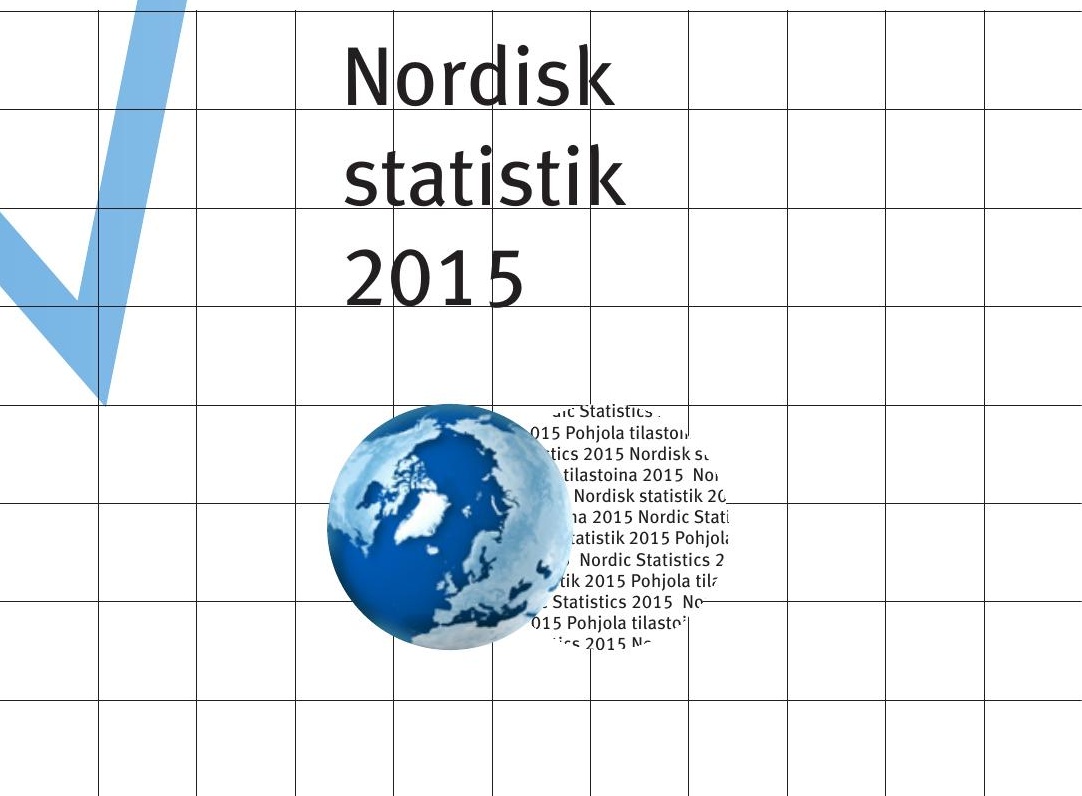




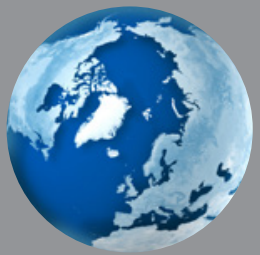

stausul.

15 Pohjola tilasto.

statistics 2015 Nordisk s

Pohjola tilastoina 2015 No stics 2015 Nordisk statistik 2i ola tilastoina 2015 Nordic Stat i Nordisk statistik 2015 Pohjol jina 2015 Nordic Statistics: k statistik 2015 Pohjola til rdic Statistics $2015 \mathrm{Nr}$ \urcorner 15 Pohjola tilastr

- inic*. 
Nordisk

statistik

2015 


\section{Nordisk statistik 2015}

ISBN 978-92-893-4366-4 (PRINT)

ISBN 978-92-893-4367-1 (PDF)

ISSN 0908-4339

http://dx.doi.org/10.6027/ANP2015-781

ANP 2015:781

(C) Nordiska ministerrådet, 2015

Omslag: Jette Koefoed/ImageSelect.

Fotos: s. 8-9: (C) ImageSelect och Nordiska ministerrådet

Tryck: Rosendahls-Schultz Grafisk A/S

Upplaga: 2 000. Printed in Denmark

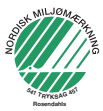

Huvudsakliga uppgiftslämnare:

De nationella statistiska instituten i de nordiska länderna.

Red: Klaus Munch Haagensen, Danmarks Statistik, Niels Stern och Johannes Magnus, Nordiska ministerådet

Databas: Troels A. Vestergaard, Danmarks Statistik.

\section{Det nordiska samarbetet}

Det nordiska samarbetet är ett av världens mest omfattande regionala samarbeten. Det omfattar Danmark, Finland, Island, Norge och Sverige samt Färöarna, Grönland och Åland.

Det nordiska samarbetet är politiskt, ekonomiskt och kulturellt förankrat och är en viktig partner i europeiskt och internationellt samarbete. Den nordiska gemenskapen arbetar för ett starkt Norden i ett starkt Europa. Det nordiska samarbetet vill stärka nordiska och regionala intressen och värderingar i en global omvärld. Gemensamma värderingar länderna emellan bidrar till att stärka Nordens ställning som en av världens mest innovativa och konkurrenskraftiga regioner.

\section{Nordiska ministerrådet}

Ved Stranden 18

DK-1061 København K

Telefon: +45 33960200

www.norden.org 


\section{Förord}

De nordiska länderna är små var för sig, men tillsammans är de betydelsefulla. Visste du till exempel att om man slår samman ländernas bruttonationalprodukter blir Norden världens tolfte största ekonomi? Eller att regionen Norden är större än hela Indien och därmed den sjunde största i världen?

Den här fickversionen av Nordisk statistik 2015 ger dig en liten inblick i statistiken som tecknar konturerna av våra nordiska samhällen - till exempel att invånarna på Island i snitt går på teater dubbelt så ofta som man gör i Norge, Danmark och Sverige.

Om du vill fördjupa dig ytterligare i nordisk statistik kan du besöka www.norden.org/fakta. Där hittar du databasen Nordisk statistikbank och fler siffror som öppnar för många intressanta analyser.

Trevlig läsning!

Mera statistik på www.norden.org/fakta
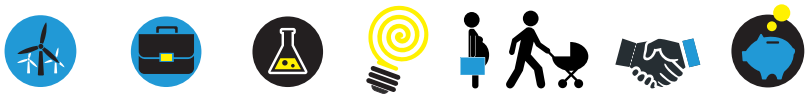
Symboler / färger / landskoder

Noll

Mindre än hälften

0

Inte tillämpligt

Uppgift saknas

Länk til databas 


\section{Innehåll / teman}

De nordiska länderna

.. statisur

J15 Pohjola tilasto. statistics 2015 Nordisk : Pohjola tilastoina 2015 No stics 2015 Nordisk statistik 21 ola tilastoina 2015 Nordic Stat ; Nordisk statistik 2015 Pohjol jina 2015 Nordic Statistics 2 'k statistik 2015 Pohjola til rdic Statistics $2015 \mathrm{~N}$ r 15 Pohjola tilastr - on1 5 .

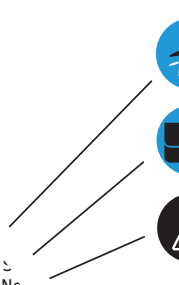

Klimat och energi

Arbetsmarknad

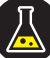

Forskning och utbildning 31

Innovation och kreativitet 39 $>$

Sociala tjänster

och jämlikhet

Förtroende och öppenhet 51

Ekonomi 


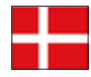

Danmark

Areal $\mathrm{km}^{2}$

43561

Befolkning

5659715

Statsskick/Status Konstitutionell monarki

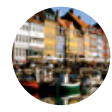

Statsöverhuvud

Drottning Margrethe II

Huvudstad

1263698

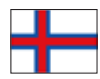

\section{Färöarna}

Areal $\mathrm{km}^{2}$

1396

Befolkning 48704

Statsskick/Status Självstyre, del av Kungariket Danmark

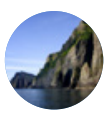
Statsöverhuvud Drottning Margrethe II

Huvudstad 20235

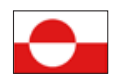

\section{Grönland}

Areal $\mathrm{km}^{2}$

Befolkning

Statsskick/Status

Statsöverhuvud

Huvudstad

\section{6}

\section{4}

Självstyre, del av Kungariket Danmark

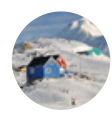
Drottning Margrethe II 16992

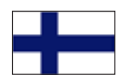

\section{Finland}

Areal km²

338430

Befolkning 5471753

Statsskick/Status

Republik

Statsöverhuvud President Sauli Niinistö

Huvudstad

1106418

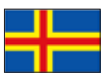

\section{Åland}

Areal $\mathrm{km}^{2}$

1580

Befolkning 28916

Statsskick/Status

Statsöverhuvud

Huvudstad

Självstyre, del av republiken Finland President Sauli Niinistö

11480

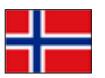

\section{Norge}

Areal km²

Befolkning

Statsskick/Status

Konstitutionell monarki

Statsöverhuvud Kung Harald V

Huvudstad 

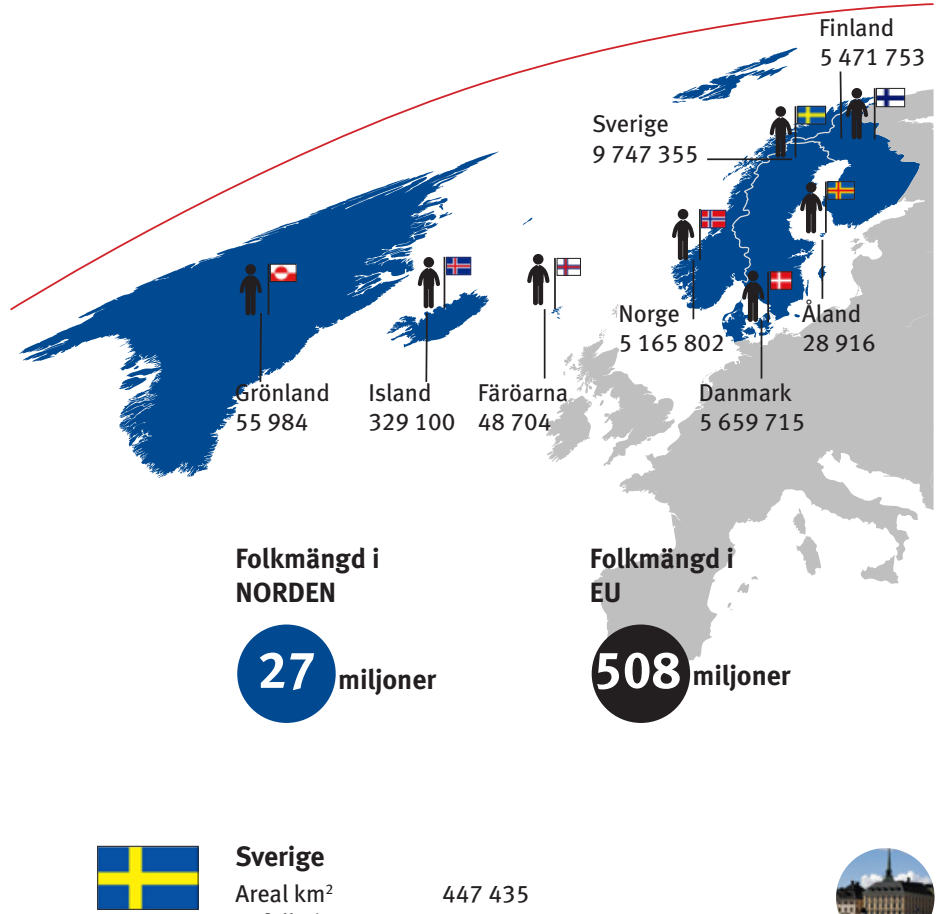

\section{Sverige}

Areal $\mathrm{km}^{2}$

447435

Befolkning

9747355

Statsskick/Status Konstitutionell monarki

Statsöverhuvud Kung Karl XVI Gustav

Huvudstad

2198044

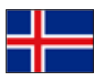

Island

Areal km²

103492

Befolkning

Statsskick/Status

329100

Statsöverhuvud

Huvudstad

Republik

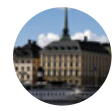

President Ólafur Ragnar Grímsson

211282

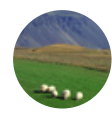


Norden i ett internationellt sammanhang - nyckeltal $2014^{1}$

\begin{tabular}{|c|c|c|c|c|}
\hline & Norden & EU & Japan & USA \\
\hline \multirow{3}{*}{$\begin{array}{l}\text { Total landareal, } 1000 \mathrm{~km}^{2} \\
\text { Åkermark, procent } \\
\text { av landareal } \\
\text { Skogsareal, procent } \\
\text { av landareal }\end{array}$} & 1147 & 4236 & 378 & 9832 \\
\hline & 7,3 & 28,4 & 12,5 & 44,7 \\
\hline & 56,1 & 37,7 & 68,6 & 33,3 \\
\hline \multirow{2}{*}{$\begin{array}{l}\text { Folkmängd, miljoner } \\
\text { Invånare per km² }\end{array}$} & 27 & 508 & 128 & 309 \\
\hline & 17 & 120 & 339 & 32 \\
\hline $\begin{array}{l}\text { Summerade fruktsamhetstal } \\
\text { Medellivslängd, antal år }\end{array}$ & 1,8 & 1,6 & 1,4 & 1,9 \\
\hline män & 79,8 & 77,8 & 79,9 & 76,4 \\
\hline kvinnor & 84,1 & 83,3 & 86,4 & 81,2 \\
\hline \multirow{3}{*}{$\begin{array}{l}\text { Arbetslöshetsprocent } \\
\text { män } \\
\text { kvinnor }\end{array}$} & 6,9 & 11,0 & 4,0 & 7,4 \\
\hline & 7,2 & 11,0 & 4,3 & 7,6 \\
\hline & 6,6 & 11,0 & 3,7 & 7,1 \\
\hline \multirow{2}{*}{$\begin{array}{l}\text { BNP (miljarder US\$ } \\
\text { BNP per person, } \\
\text { PPS (US\$) }\end{array}$} & 1256 & 18430 & 4636 & 17419 \\
\hline & 47598 & 34083 & 36485 & 54639 \\
\hline \multirow{2}{*}{$\begin{array}{l}\text { Samtliga skatter } \\
\text { i procent av BNP } \\
\text { Samtliga skatter } \\
\text { per person (US\$) }\end{array}$} & 43,8 & 48,6 & 29,5 & 25,4 \\
\hline & 28961 & 16088 & 13711 & 13783 \\
\hline Import C.I.F. (miljarder US\$) & 432 & 2227 & 785 & 2295 \\
\hline Export F.O.B. (miljarder US\$) & 530 & 2256 & 695 & 1593 \\
\hline Handelsbalans (miljarder US\$) & 98 & 29 & -90 & -702 \\
\hline
\end{tabular}

${ }^{1} 2014$ eller senast tillgängliga siffror. Norden består i denna tabell av Danmark, Finland, Island, Norge och Sverige. EU: De 27 eller 28 medlemsstaterna i Europeiska unionen per 1 januari 2013 eller 1 januari 2014. PPS: Purchasing power standards - köpkrafts-

pariteter som eliminerar skillnader i prisnivå mellan länderna. 


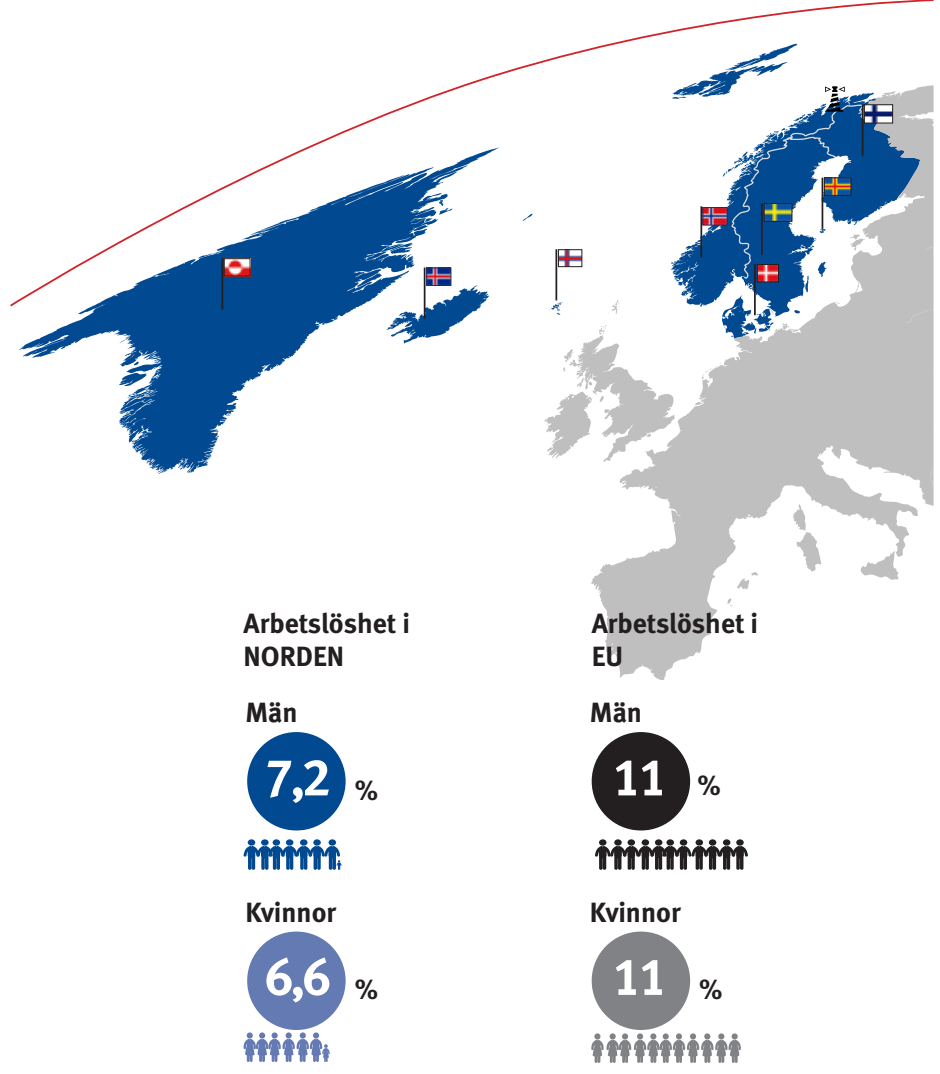


. statistic.

15 Pohjola tilasto. statistics 2015 Nordisk s Pohjola tilastoina 2015 No stics 2015 Nordisk statistik 21 ola tilastoina 2015 Nordic Stat ; Nordisk statistik 2015 Pohjol jina 2015 Nordic Statistics : k statistik 2015 Pohjola til rdic Statistics $2015 \mathrm{Nr}$

115 Pohjola tilastr

? $21 \mathrm{E}$. 
Visste du att ...

sedan år 1995 har de nordiska ekonomierna nästan fördubblats

samtidigt som koldioxidutsläppen har minskat med nästan

20 procent?

(Källa: Nordisk statistik)

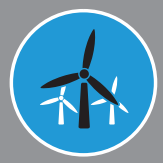

Klimat och energi 
... och att de nordiska

länderna ligger 25 år före resten av världen när det gäller att minska användningen av kol i elproduktionen?

(Källa: IEA) 


\section{Medeltemperatur i de nordiska huvudstäderna}

10 Grader Celsius

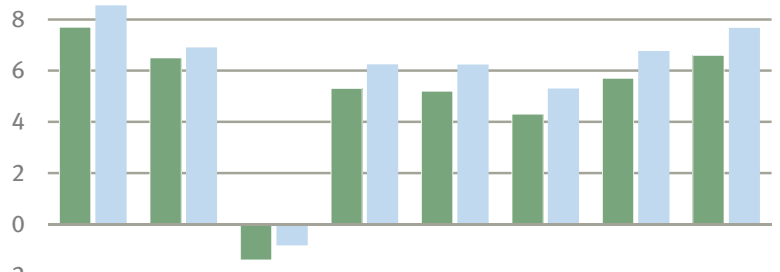

$-2$
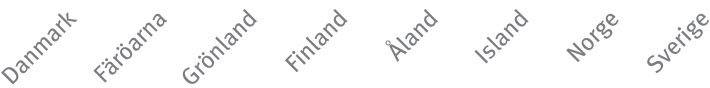

• Medeltemperatur 1961-1990 Medeltemperatur 1990-2014

므 Temp01. Färöarna, Norge och Sverige: 1990-2013 års uppgifter. Island: 1997-2014 års uppgifter.

\section{Utsläpp av växthusgaser, per person}

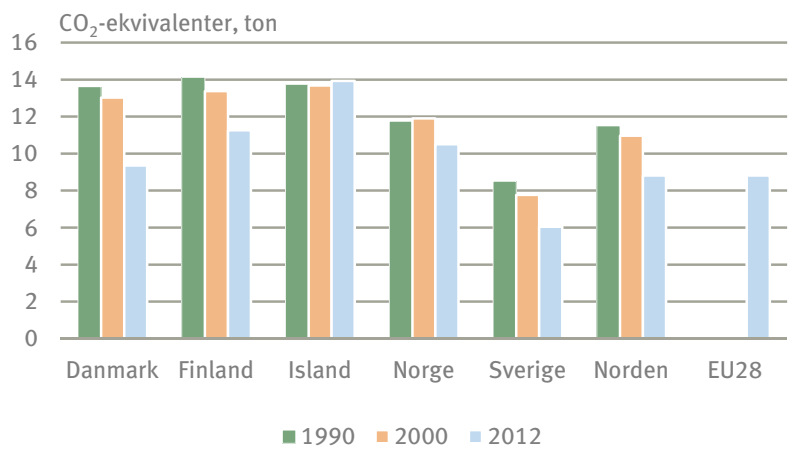

Emis11 och Popu02 
Inhemsk energiproduktion 2013

\section{Norden}

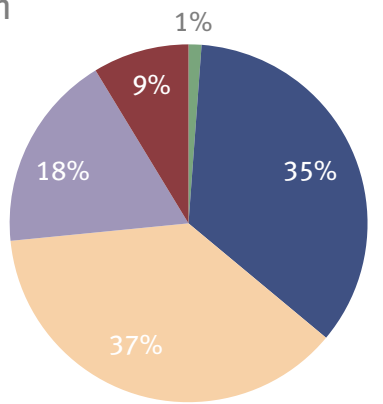

\section{Ener06}

Inhemsk energiproduktion 2013

\section{EU27}

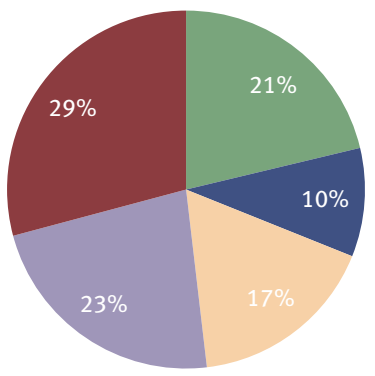

- Kol

口 Olja

Gas

— Förnyelsebara bränslen

— Kärnkraft 
Energitillgång efter bränsleslag 2013

Norden

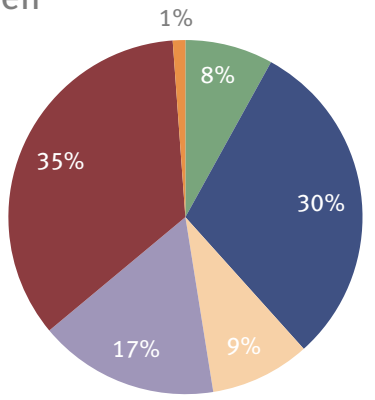

- Kol

- Olja

Gas

- Kärnkraft

- Förnyelsebara bränslen

묘 Ener05

Energitillgång efter bränsleslag 2013

\section{EU28}

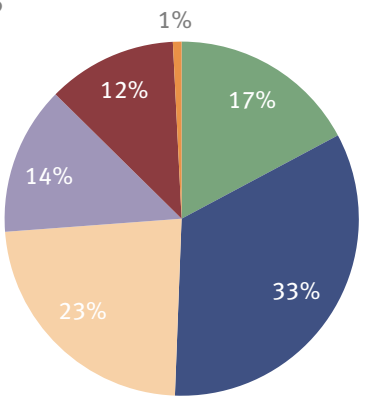

- Kol

- Olja

Was

- Kärnkraft

- Förnyelsebara bränslen

Ener05 
Slutlig inhemsk energiförbrukning 2013

Norden

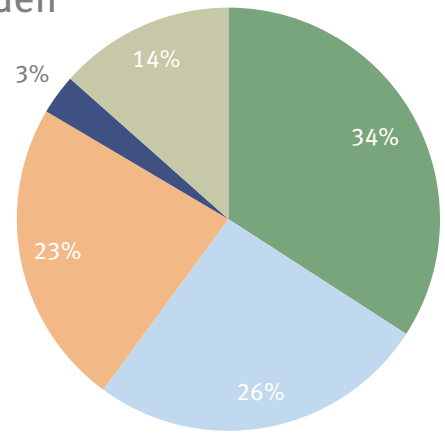

- Industri

in Transporter

- Hushåll

- Jordbruk och fiske

- Service och övriga sektorer

Slutlig inhemsk energiförbrukning 2013

\section{EU28}

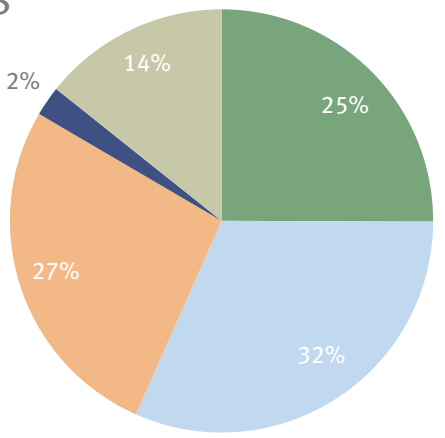

- Industri

- Transporter

nushåll

- Jordbruk och fiske

Service och övriga sektorer 
Avlänkning mellan miljöbelastning och ekonomisk tillväxt

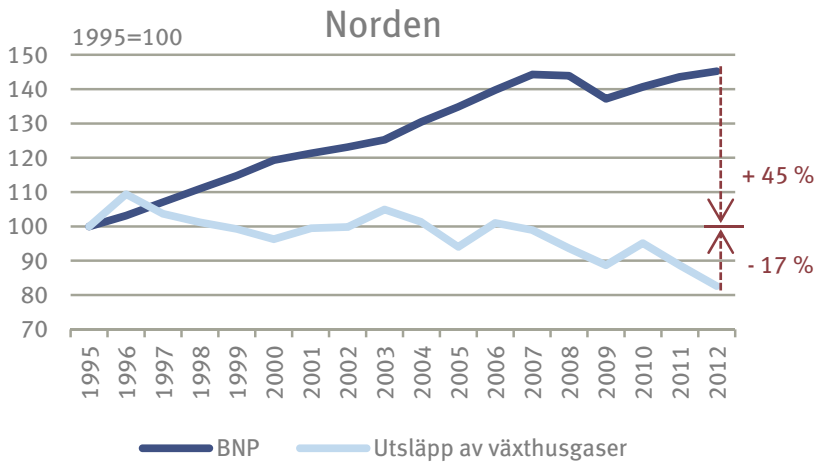

Avlänkning mellan miljöbelastning och ekonomisk tillväxt

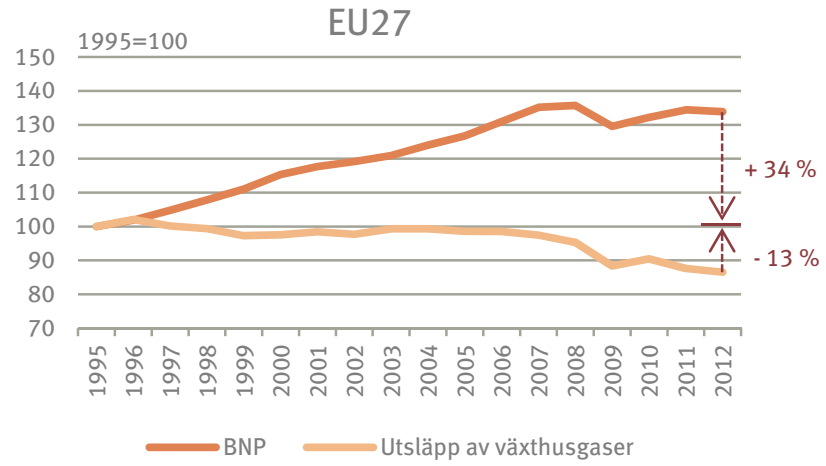

Indic401 


\section{Miljöskatter}

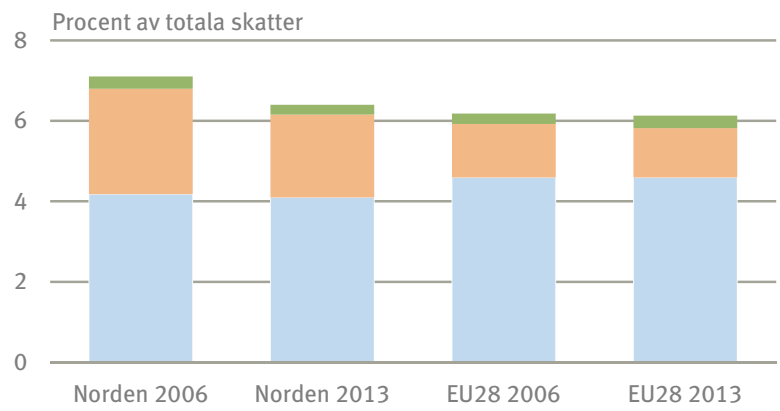

- Skatter på föroreningar och resurser $\quad$ Transportskatter Energiskatter ㅁobs15 


\section{Ekologiskt jordbruk 2013}

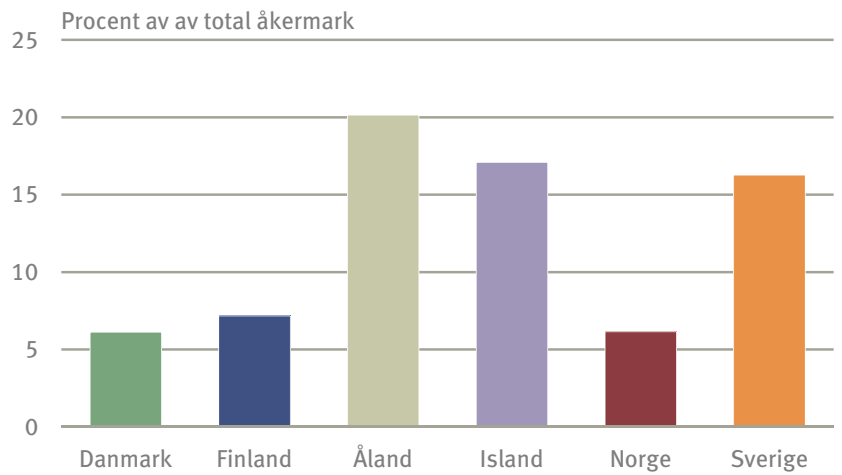

Oeko01. Finland, Norge och Sverige: 2012 års uppgifter. 
. statistic.

15 Pohjola tilasto.

statistics 2015 Nordisk s

Pohjola tilastoina 2015 No

stics 2015 Nordisk statistik 21

ola tilastoina 2015 Nordic Stat

; Nordisk statistik 2015 Pohjol

jina 2015 Nordic Statistics:

k statistik 2015 Pohjola til

rdic Statistics $2015 \mathrm{Nr}$

115 Pohjola tilastr

- 2n1 E A. 
Visste du att ...

30 procent av alla anställda i Norden jobbar inom den offentliga sektorn?

(Källa: Nordisk statistik)

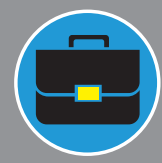

Arbetsmarknad 


\section{Sysselsättningsgrad 2014}

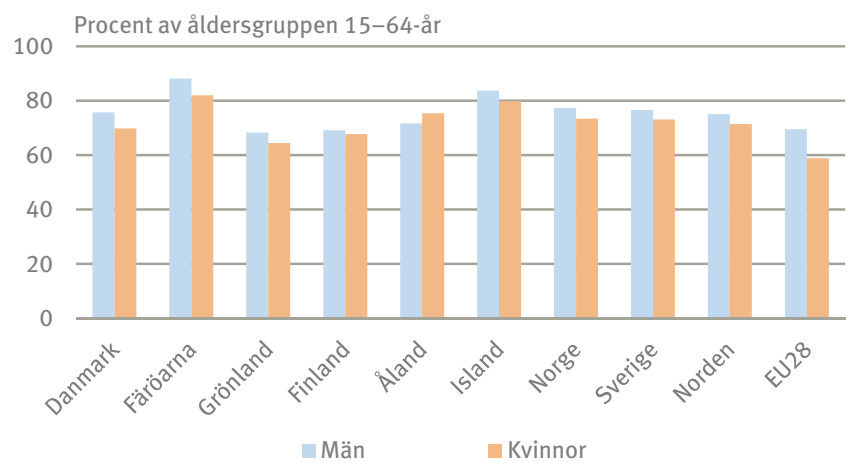

\section{Alla sysselsatta efter kön 2014}

\section{Norden}

\section{EU28}
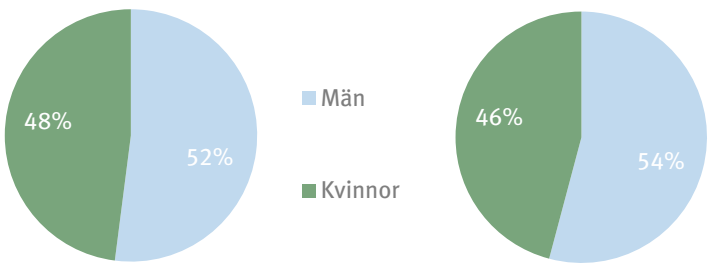

$\square$ Work02. Åland: 2011 års uppgifter. Grönland, Finland, Island och Norge: 2013 års uppgifter. 


\section{Arbetslöshet}

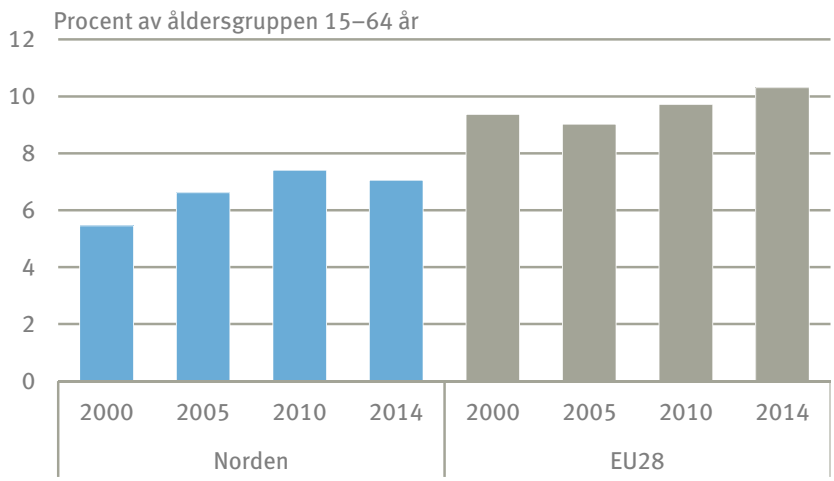

马 Work02

\section{Ungdomsarbetslöshet}

\section{Procent av åldersgruppen 15-24 år}

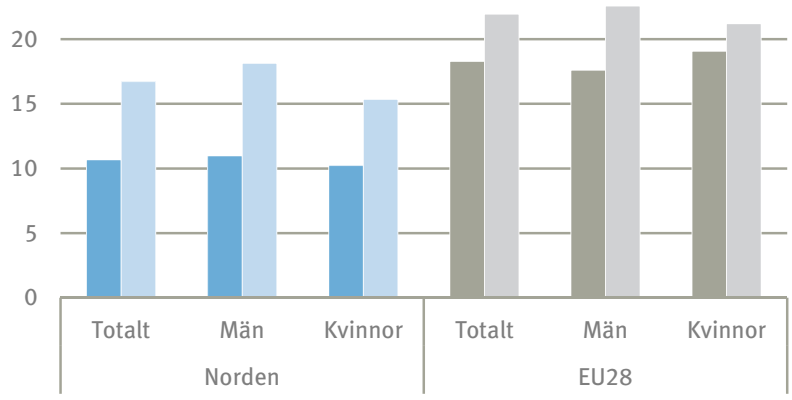

- 2000 = 2014

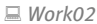


Arbetsfrånvaro minst en vecka på grund av sjukdom

5 Procent av de sysselsatta

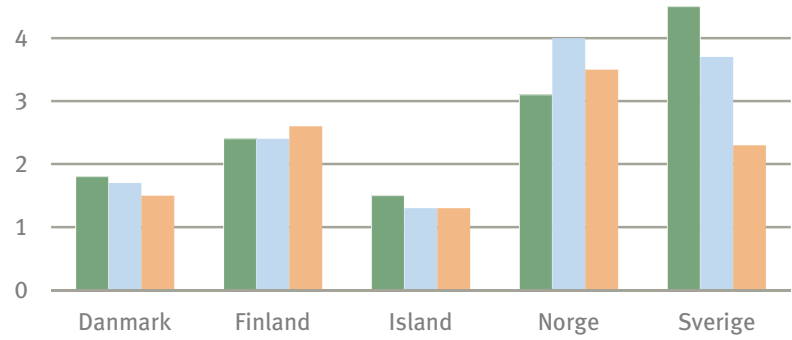

- $1990 \quad 2000 \square 2013$

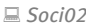

Arbetsfrånvaro minst en vecka på grund av sjukdom 2013

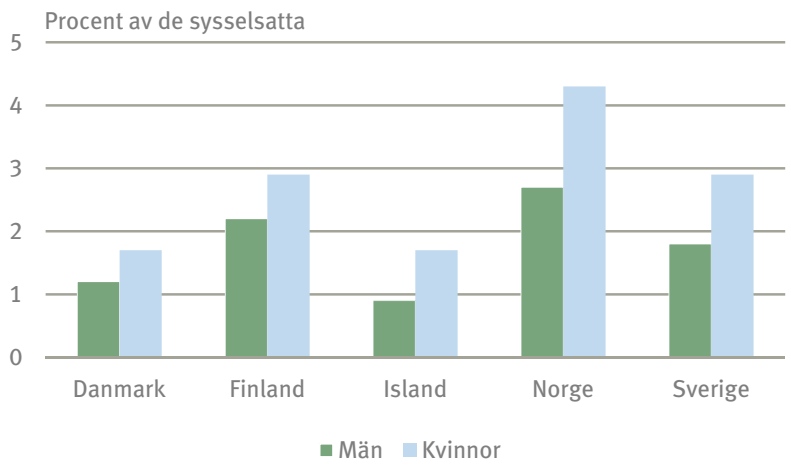

马oci02 


\section{Havandeskaps- och föräldrapenning}

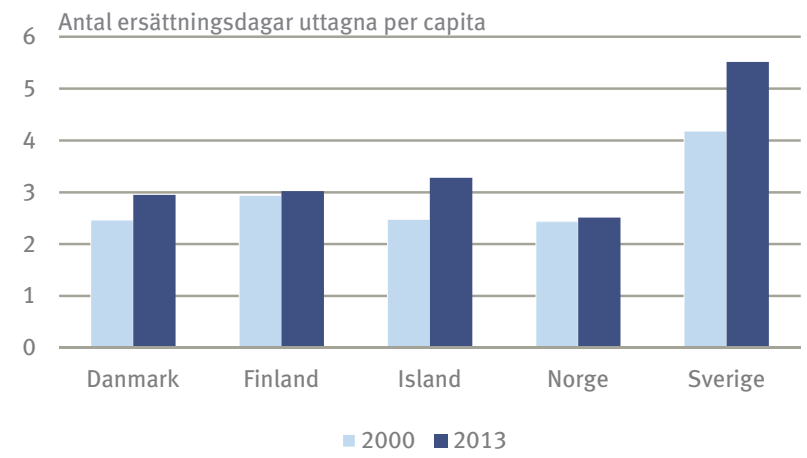

Soci04

\section{Havandeskaps- och föräldrapenning}

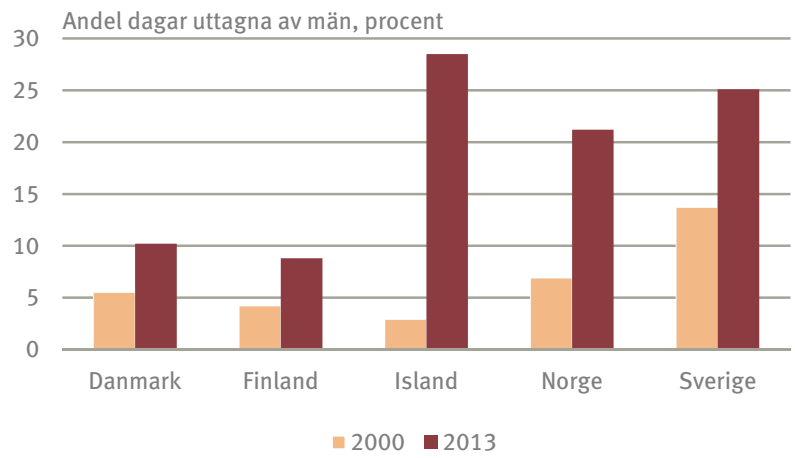

马 Soci04. Sverige: 2012 års uppgifter. 


\section{Årlig medianinkomst 2013}

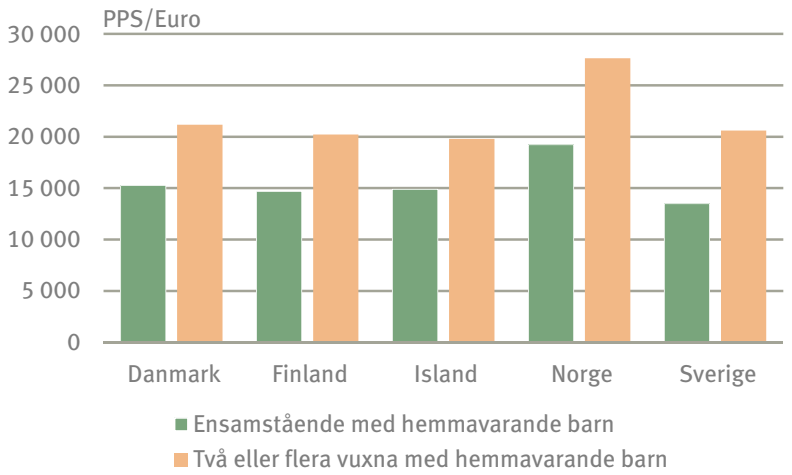

口 Inco02. Sverige: 2012 års uppgifter. 


\section{Visste du att ... två tredjedelar av alla kvinnor i Norden jobbar heltid?}

(Källa: Nordisk statistik) 
. statistic.

15 Pohjola tilasto.

statistics 2015 Nordisk s

Pohjola tilastoina 2015 No

stics 2015 Nordisk statistik 21

ola tilastoina 2015 Nordic Stat

; Nordisk statistik 2015 Pohjol

jina 2015 Nordic Statistics:

k statistik 2015 Pohjola til

rdic Statistics $2015 \mathrm{Nr}$

115 Pohjola tilastr

- 2n1 E A. 
Visste du att ...

det idag finns mer än tre gånger så många läkare per invånare än vad det gjorde på 60-talet?

(Källa: Nordisk statistik)

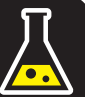

Forskning och utbildning 
Utbildningsnivå (i åldern 25-74) 2014

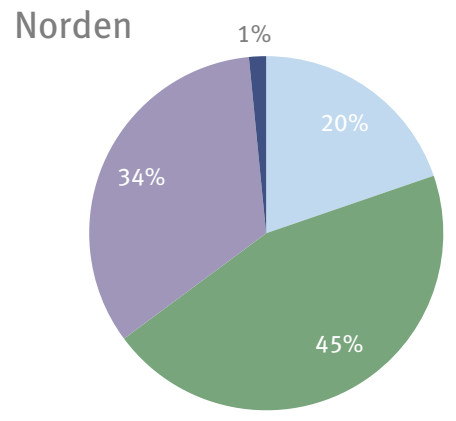

Grundskola (ISCED 1+2)

- Gymnasium och yrkesutbildning (ISCED $3+4)$

- Universitet och högskola (ISCED 5+6)

- Ospecificerat

Utbildningsnivå (i åldern 25-74) 2014

\section{EU27}

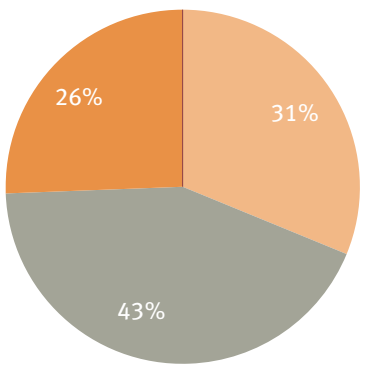

- Grundskola (ISCED $1+2)$

- Gymnasium och yrkesutbildning (ISCED 3+4)

- Universitet och högskola (ISCED 5+6)

- Ospecificerat 
Elevers prestationer, PISA 2012

\begin{tabular}{|c|c|c|c|c|c|}
\hline \multicolumn{2}{|l|}{ Läsförståelse } & \multicolumn{2}{|c|}{ Kunskaper i matematik } & \multicolumn{2}{|l|}{$\begin{array}{l}\text { Kunskaper i } \\
\text { naturvetenskap }\end{array}$} \\
\hline Japan & 538 & Sydkorea & 554 & Japan & 547 \\
\hline Sydkorea & 536 & Japan & 536 & Finland & 545 \\
\hline Finland & 524 & Schweiz & 531 & Estland & 541 \\
\hline Kanada & 523 & Nederländerna & 523 & Sydkorea & 538 \\
\hline Irland & 523 & Estland & 521 & Polen & 526 \\
\hline Polen & 518 & Finland & 519 & Kanada & 525 \\
\hline Estland & 516 & Kanada & 518 & Tyskland & 524 \\
\hline Nya Zeeland & 512 & Polen & 518 & Nederländerna & 522 \\
\hline Australien & 512 & Belgien & 515 & Irland & 522 \\
\hline Nederländerna & 511 & Tyskland & 514 & Australien & 521 \\
\hline Belgien & 509 & Österrike & 506 & Nya Zeeland & 516 \\
\hline Schweiz & 509 & Australien & 504 & Schweiz & 515 \\
\hline Tyskland & 508 & Slovenien & 501 & Storbritannien & 514 \\
\hline Frankrike & 505 & Irland & 501 & Slovenien & 514 \\
\hline Norge & 504 & Nya Zeeland & 500 & Tjeckien & 508 \\
\hline Storbritannien & 499 & Danmark & 500 & Österrike & 506 \\
\hline USA & 498 & Tjeckien & 499 & Belgien & 505 \\
\hline Danmark & 496 & Frankrike & 495 & OECD & 501 \\
\hline OECD & 496 & OECD & 494 & Frankrike & 499 \\
\hline Tjeckien & 493 & Storbritannien & 494 & Danmark & 498 \\
\hline Italien & 490 & Island & 493 & USA & 497 \\
\hline Österrike & 490 & Luxemburg & 490 & Spanien & 496 \\
\hline Ungern & 488 & Norge & 489 & Norge & 495 \\
\hline Portugal & 488 & Portugal & 487 & Ungern & 494 \\
\hline Spanien & 488 & Italien & 485 & Italien & 494 \\
\hline Luxemburg & 488 & Spanien & 484 & Luxemburg & 491 \\
\hline Israel & 486 & Slovakien & 482 & Portugal & 489 \\
\hline Island & 483 & USA & 481 & Sverige & 485 \\
\hline Sverige & 483 & Sverige & 478 & Island & 478 \\
\hline Slovenien & 481 & Ungern & 477 & Slovakien & 471 \\
\hline Grekland & 477 & Israel & 466 & Israel & 470 \\
\hline Turkiet & 475 & Grekland & 453 & Grekland & 467 \\
\hline Slovakien & 463 & Turkiet & 448 & Turkiet & 463 \\
\hline Chile & 441 & Chile & 423 & Chile & 445 \\
\hline Mexiko & 424 & Mexiko & 413 & Mexiko & 415 \\
\hline
\end{tabular}

马isa01 


\section{Studerande på universitet och högskola}

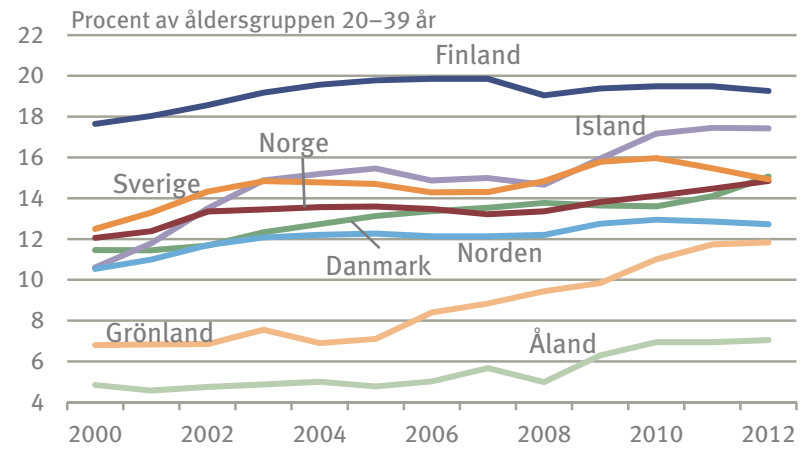

\section{Studerande på universitet och högskola}

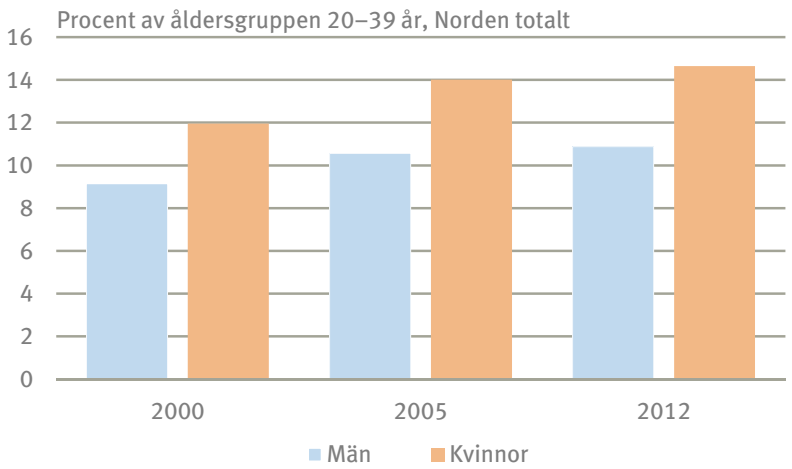

巨Educ02 och Popu02 


\section{Studiestöd 2013}

1400 Euro per månad

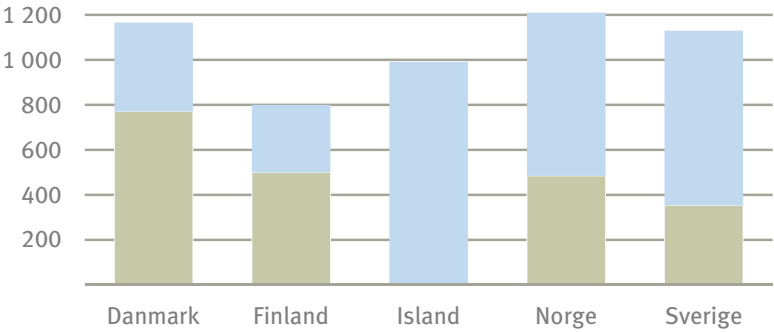

n Bidrag —Lån

Educ07

Filosofie doktorer 2012

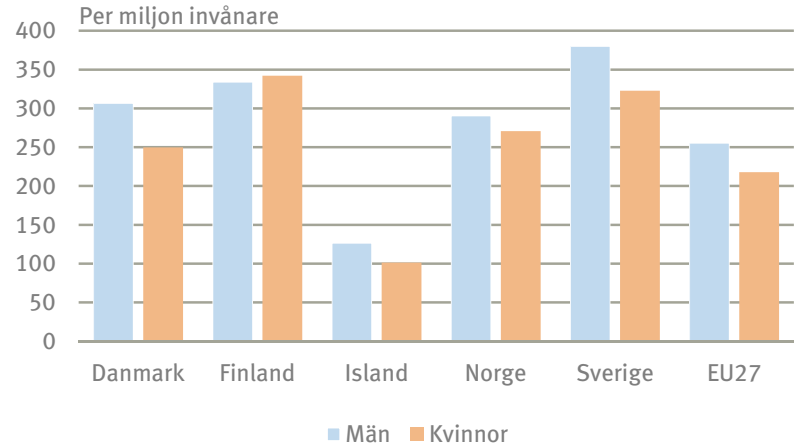

口 Phdg01 


\section{FoU-personal}

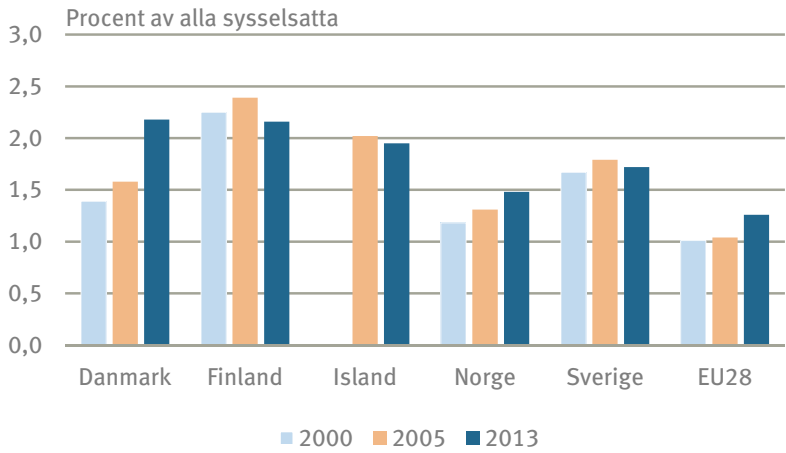

口 Rede04

\section{Totala statliga FoU-utgifter}

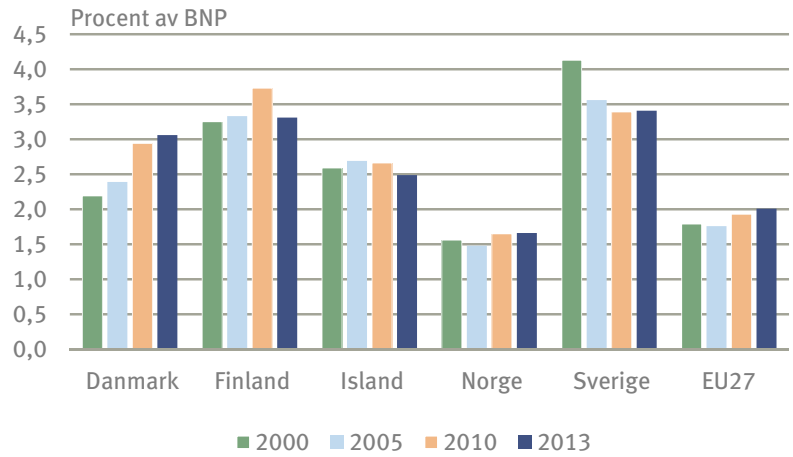

묘 Rede01 
Nybildade företag

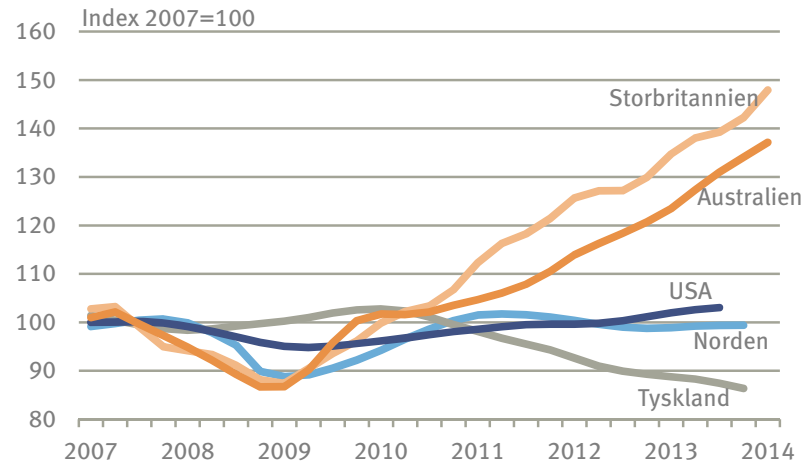

ㅌtp02

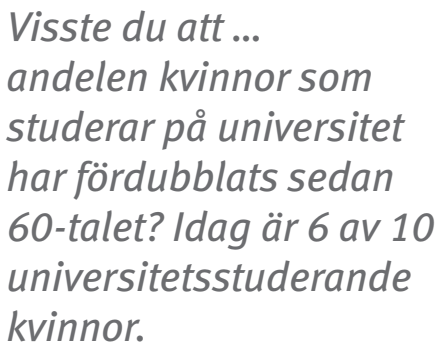

(Källa: Nordisk statistik) 
. statistic.

15 Pohjola tilasto.

statistics 2015 Nordisk s

Pohjola tilastoina 2015 No

stics 2015 Nordisk statistik 21

ola tilastoina 2015 Nordic Stat

; Nordisk statistik 2015 Pohjol

jina 2015 Nordic Statistics:

k statistik 2015 Pohjola til

rdic Statistics $2015 \mathrm{Nr}$

115 Pohjola tilastr

- 2n1 E A. 
Visste du att ...

sedan år 2000 har de

nordiska länderna haft

en ökning på 30-80

procent av andra medier

än böcker samtidigt som

utlåning av böcker har

minskat med 10-20

procent?

(Källa: Nordisk statistik)

Innovation och kreativitet 


\section{Patent 2014}

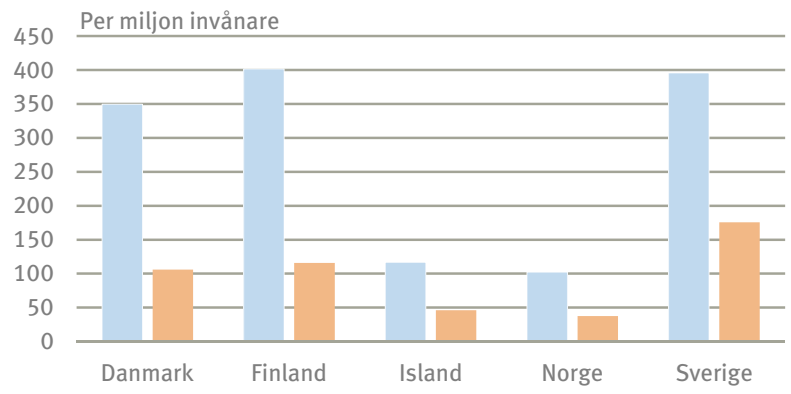

—Inlämnade ansökningar $\quad$ Beviljade patent

\section{Anställda inom kultursektorn}

5,0 Procent av den totala sysselsättningen

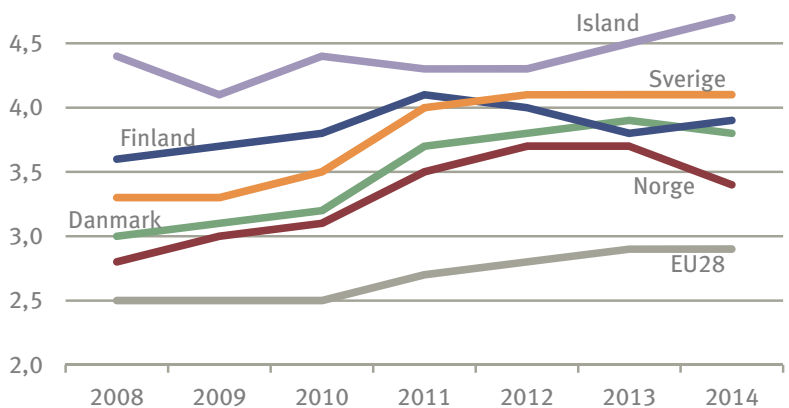


Offentlig finansiering av kultur- och fritidsverksamhet 2013

1400 Euro per invånare

1200

1000

800

600

400

200

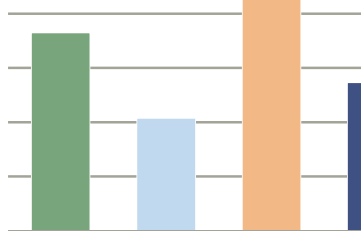

Danmark Färöarna Grönland Finland Island

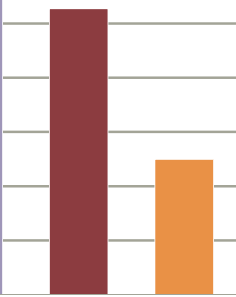

Norge Sverige

므 Cult20. Färöarna: 2009 års uppgifter. Grönland: 2012 års uppgifter.

Offentlig finansiering av kultur- och fritidsverksamhet

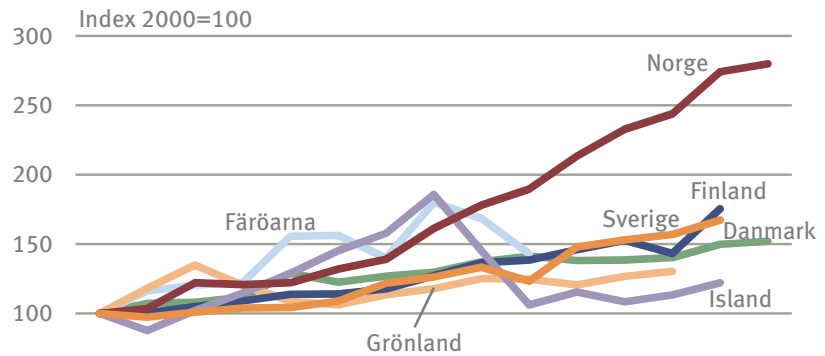

50

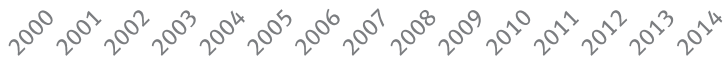

믄 Cult20 


\section{Filmpremiärer 2013}

Andel av de nordiska filmpremiärer

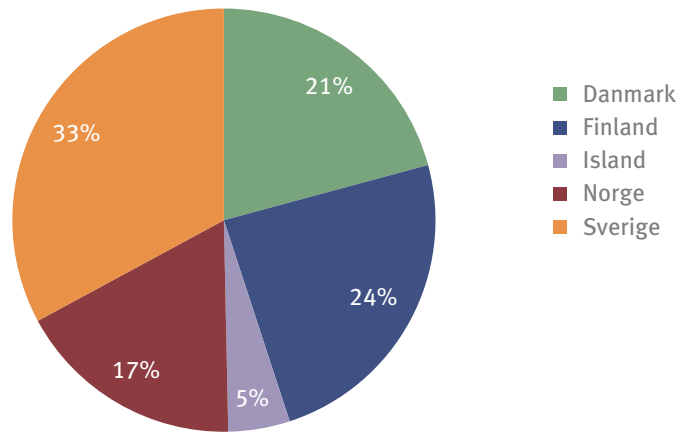

묘인

Filmpremiärer 2013

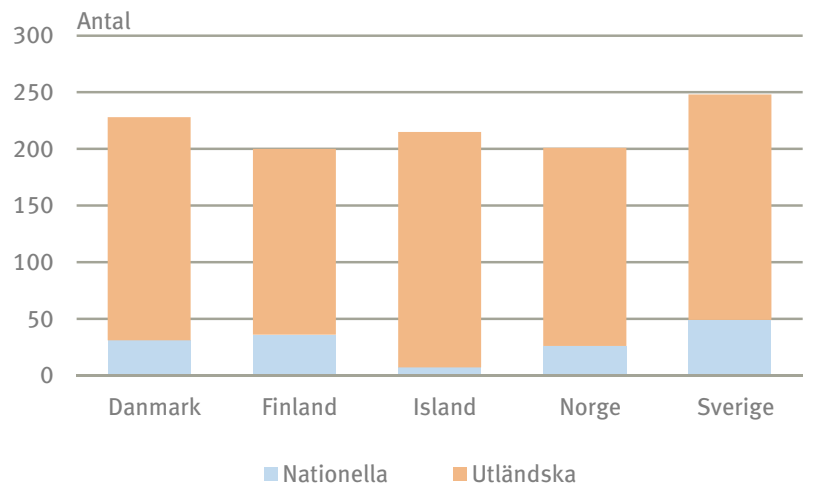

昌 Cult05 
Teaterbesök 2014

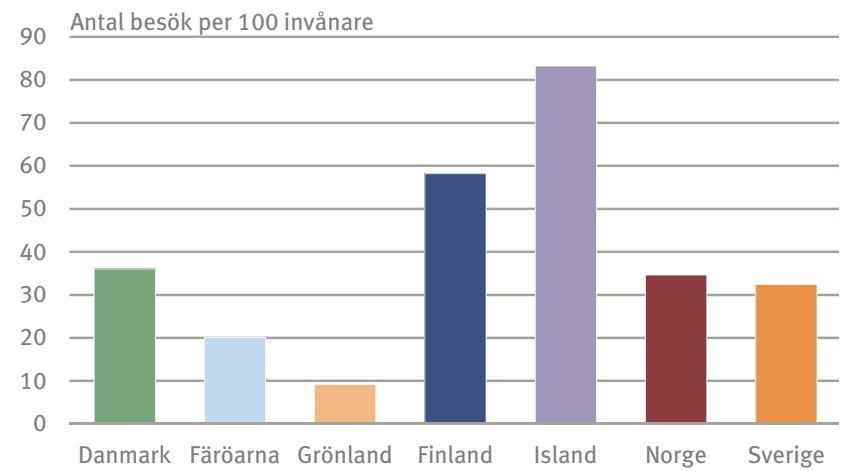

믈. Cult15. Island: 2012 års uppgifter. Sverige: 2010 års uppgifter.

Visste du att ... det finns sammanlagt 406 teatrar som visar mer än 60000 föreställningar i hela Norden varje år?

(Källa: Nordisk statistik) 
. statistic.

15 Pohjola tilasto.

statistics 2015 Nordisk s

Pohjola tilastoina 2015 No

stics 2015 Nordisk statistik 21

ola tilastoina 2015 Nordic Stat

; Nordisk statistik 2015 Pohjol

jina 2015 Nordic Statistics:

k statistik 2015 Pohjola til

rdic Statistics $2015 \mathrm{Nr}$

115 Pohjola tilastr

- 2n1 E A. 
Visste du att ...

de nordiska länderna

är bäst utrustade för

att uppnå FN:s mål för hållbar utveckling?

(Källa: Sustainable Governance Indicators 2015)

... och att den förväntade livslängden för kvinnor är nu 84 år? I början av 60-talet var den förväntade livslängden "bara" 74 år.

(Källa: Nordisk statistik)

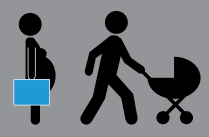

Sociala tjänster och jämlikhet 
Gini-koefficienten 2013

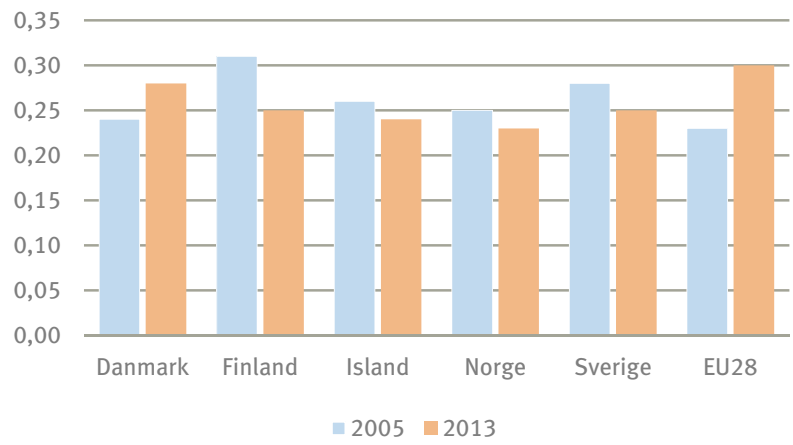

므 Gini01. Färöarna: 2005=2009 års uppgifter. EU28: Uppgifterna för 2005 gäller EU27.

\section{Sociala utgifter efter finansieringskälla 2012}

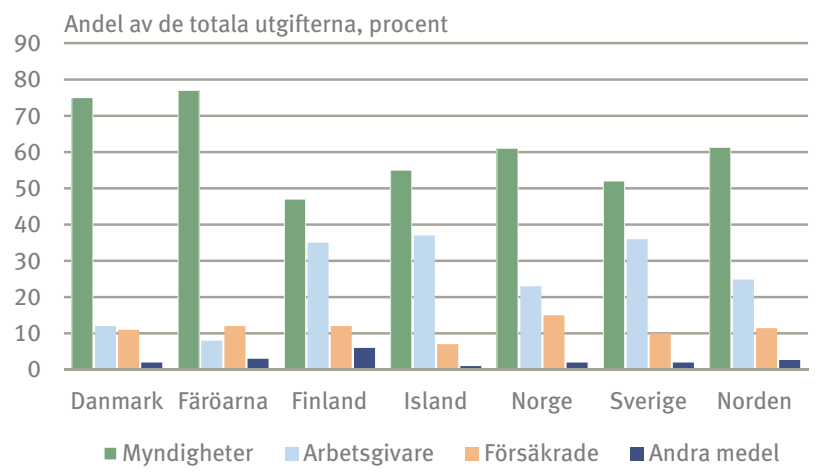

묘요으 


\section{Mottagare av utkomststöd 2013}

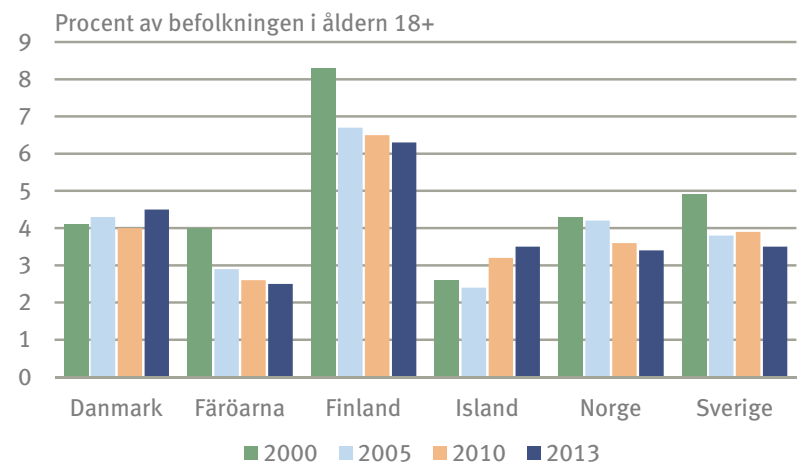

且 Soci12. Färöarna: 2013=2011 års uppgifter. Finland och Norge: 2013=2012 års uppgifter.

\section{Risk för fattigdom 2013}

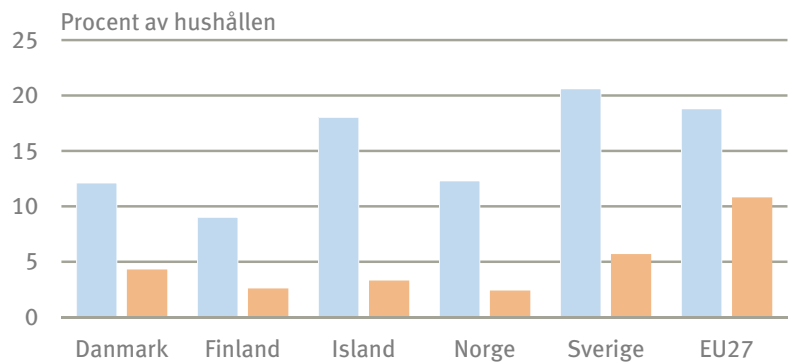

- Ensamstående förälder med hemmavarande barn

- Två eller flera vuxna med hemmavarande barn

$\boxminus$ Riop01 
Löneskillnader mellan könen (till fördel för män)

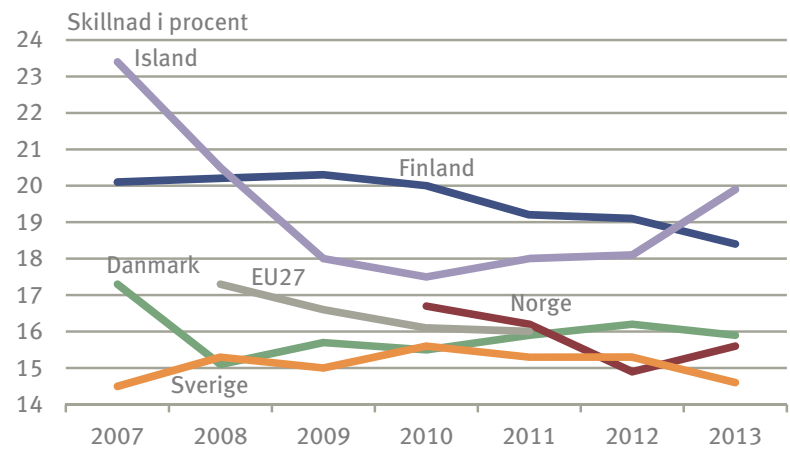

昌 Indic109

Invalda ledamöter till de nationella parlamenten. Senaste valet.

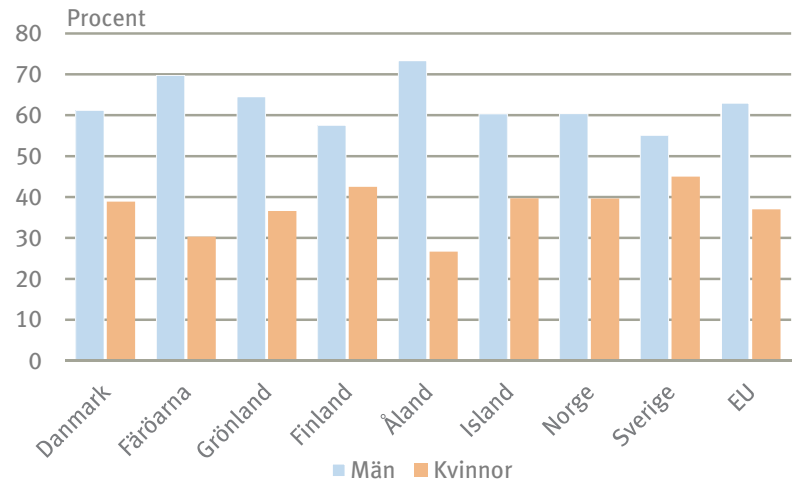

Ele03 
Giltiga röster vid de två senaste nationella valen

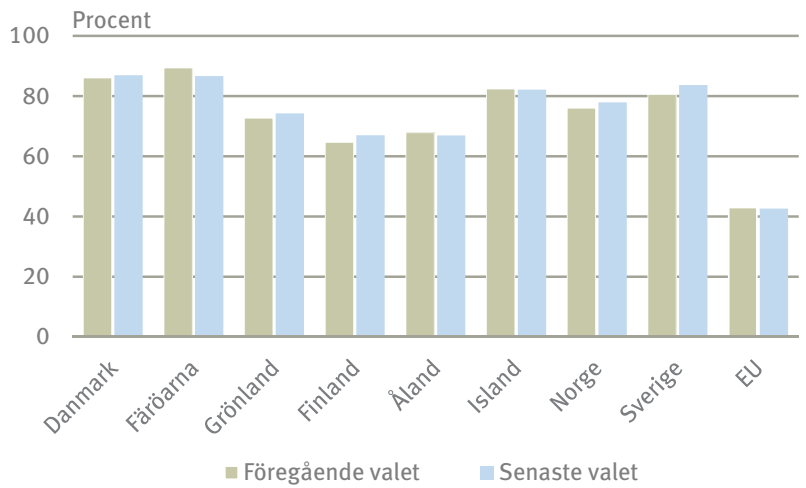

ㅌe Ele01

Invandring till de nordiska länderna 2014

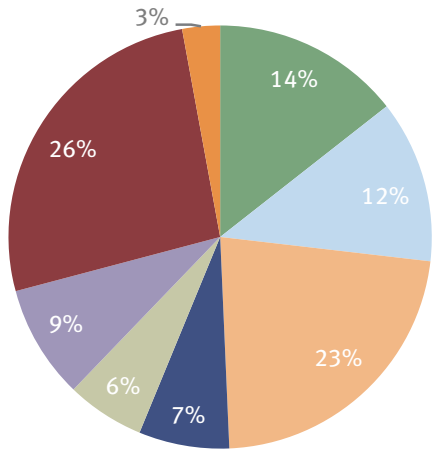

- Inom Norden

- Polen och Baltikum

— Övriga EES

- Övriga Europa

- Amerika

- Afrika

- Asien

- Övriga

Migr01 
. statistic.

15 Pohjola tilasto.

statistics 2015 Nordisk s

Pohjola tilastoina 2015 No

stics 2015 Nordisk statistik 21

ola tilastoina 2015 Nordic Stat

; Nordisk statistik 2015 Pohjol

jina 2015 Nordic Statistics:

k statistik 2015 Pohjola til

rdic Statistics $2015 \mathrm{Nr}$

115 Pohjola tilastr

- 2n1 E A. 
Visste du att ... i början av 60-talet kom över hälften av invandrarna till Norden från ett annat nordiskt land? Idag kommer de flesta från andra länder i Europa. 


\section{Utvandring från de nordiska länderna 2014}

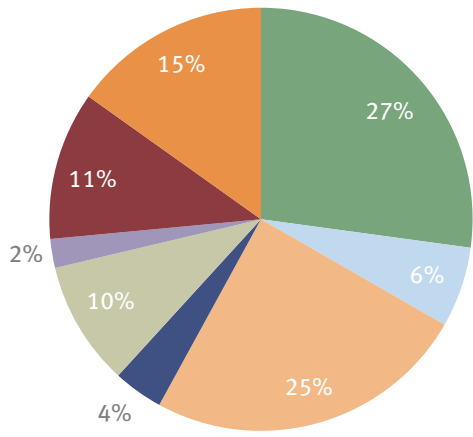

Inom Norden

Polen och Baltikum

- Övriga EES

- Övriga Europa

Amerika

Afrika

- Asien

- Övriga

马 Migr02. Finland: 2013 års uppgifter.

Asylansökningar och beviljade asyl i de nordiska länderna

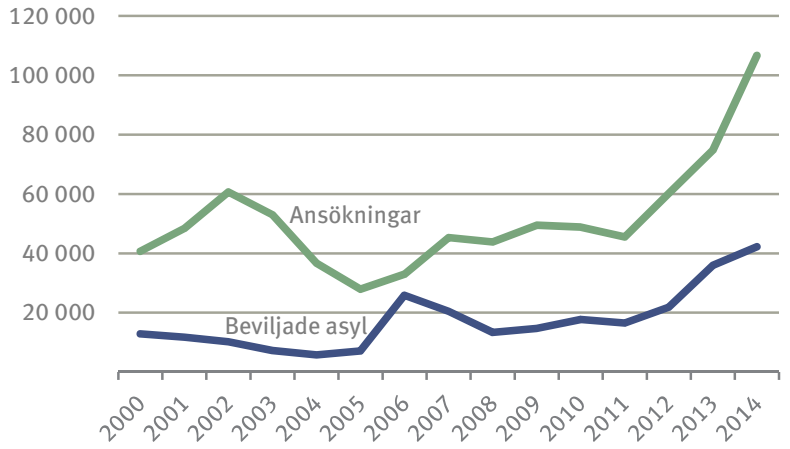

Migr04 
Asylansökningar till de nordiska länderna 2014

Andel av ansökningarna

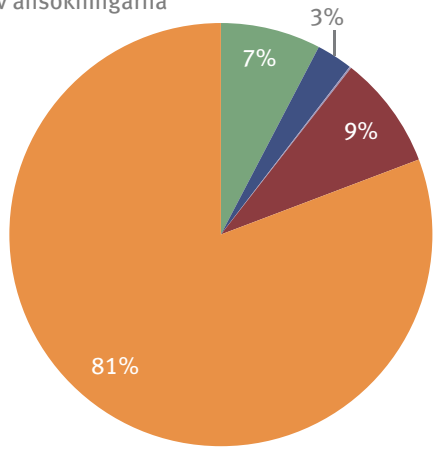

nanmark

- Finland

- Island

- Norge

nverige

Beviljade asyl i de nordiska länderna 2014

Andel av beviljade asyl

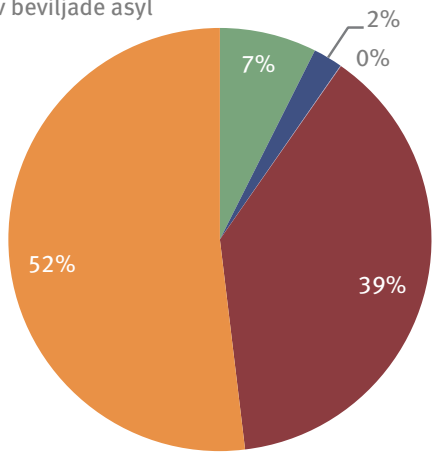

Eanmark

- Finland

- Island

- Norge

- Sverige

매요 Migr04. Finland: 2013 års uppgifter. 


\section{Ensamkommande barn som söker asyl}

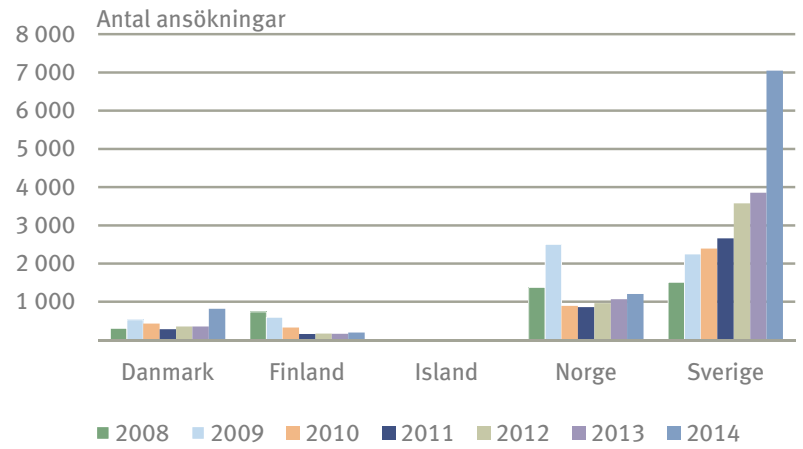

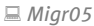




\section{Visste du att ... under de senaste åren har det totala antalet asylansökningar per år i Norden varierat mellan 45000 och 75000 ?}

(Källa: Nordisk statistik) 
. statistic.

15 Pohjola tilasto.

statistics 2015 Nordisk s

Pohjola tilastoina 2015 No

stics 2015 Nordisk statistik 21

ola tilastoina 2015 Nordic Stat

; Nordisk statistik 2015 Pohjol

jina 2015 Nordic Statistics:

k statistik 2015 Pohjola til

rdic Statistics $2015 \mathrm{Nr}$

115 Pohjola tilastr

- 2n1 E A. 
Visste du att ...

tillsammans är de nordiska länderna den tolfte största ekonomin i världen med en sammanlagd BNP på 1,5 biljoner euro?

(Källa: Världsbanken)

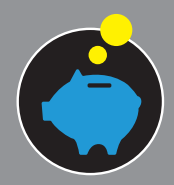

Ekonomi 
Ekonomiska nyckeltal $2014^{1}$

Danmark Finland Island Norge Sverige EA19

Procent av BNP

Bytesbalans över-

skott

$6,3 \quad-1,9 \quad 3,6 \quad 8,5 \quad 6,3$

Utländska tillgångar,

netto, 31 Dec. 2013

$40,0 \quad 46,0 \quad-422,0 \quad 134,0$

Offentliga sektorns

överskott

$\begin{array}{lllll}1,2 & -3,2 & -0,2 & 9,1 & -1,9\end{array}$

Offentliga sektorns

skulder, 31 Dec. 2013

$\begin{array}{llllll}45,2 & 59,3 & 99,0 & 26,4 & 43,9 & 91,9\end{array}$

Per cent

Arbetslöshetstal

$\begin{array}{rrrrrr}6,6 & 8,7 & 5,0 & 3,5 & 7,9 & 11,6 \\ 1,3 & 1,4 & 6,4 & 2,5 & 1,7 & . .\end{array}$

Ränta

$1,3 \quad 1,4$

Procentuell förän-

dring 2013-2014

Tillväxt i

konsumentpriser

Ekonomisk tillväxt

0,3

1,2

1,0

1,9

0,2

0,4

Aktiekursindex

$0,4 \quad-1,4$

3,3

0,6

1,6

$-0,4$

Effektivt nominellt

valutakursindex

$30,0 \quad 16,6$

11,9

15,7

13,5

$\begin{array}{lllll}-8,4 & -8,5 & -8,8 & -8,3 & -8,3\end{array}$

ey01. ${ }^{1} 2014$ eller senast tillgängliga uppgifter. EA19: De 19 europeiska länderna som har infört euron som gemensam valuta per 1 januari 2015.

Visste du att ...

drygt 70 procent

av alla anställda $i$

Norden jobbar inom

servicesektorn?

(Källa: Nordisk statistik) 


\section{Bruttonationalprodukt per person}

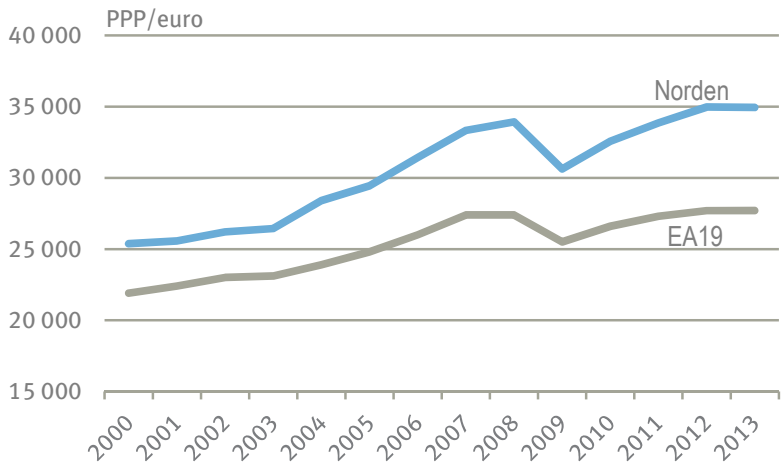

므dic102.

\section{Bruttonationalprodukt per person}

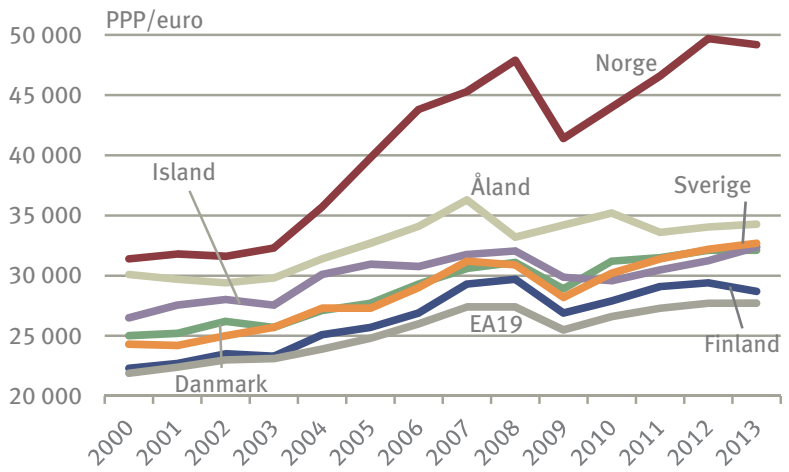

@ Indic102. EA19: De 19 europeiska länderna som har infört euron som gemensam valuta per 1 januari 2015. 


\section{Bruttonationalprodukt, årlig realtillväxt}

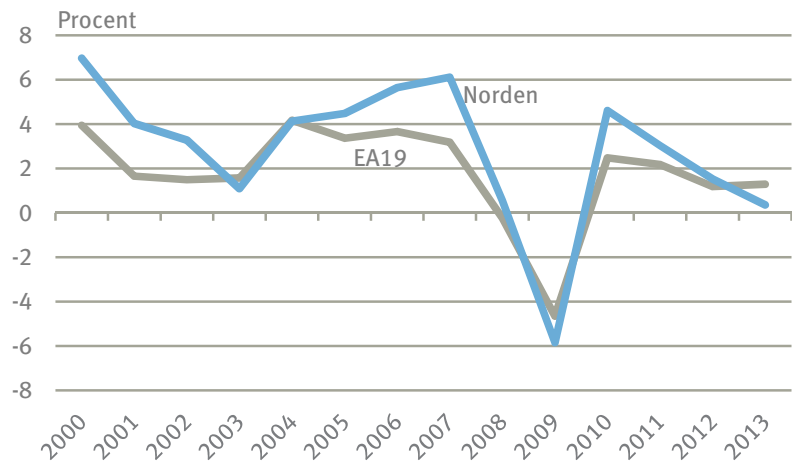

\section{Bruttonationalprodukt, årlig realtillväxt}

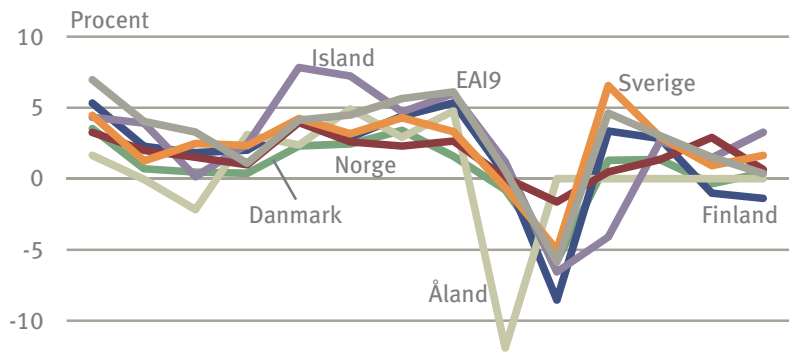

$-15$

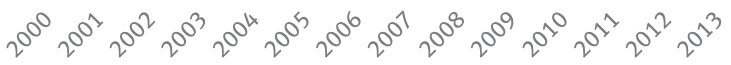

Naac04. EA19: De 19 europeiska länderna som har infört euron som gemensam valuta per 1 januari 2015. 
Handelsbalans för varor - export minus import

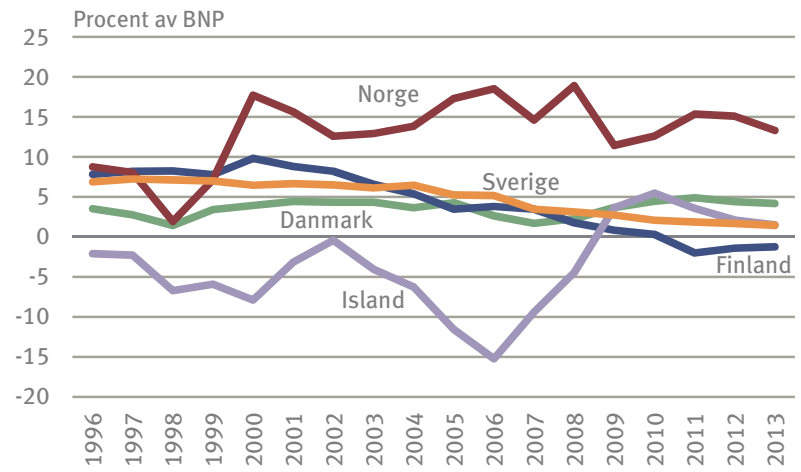

Fotr49

Handel med varor mellan de nordiska länderna

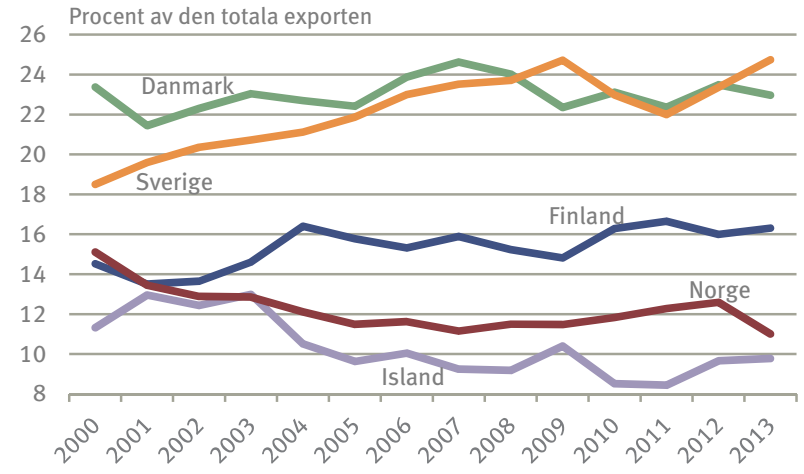

Fotr44 
Handel med varor mellan de nordiska länderna

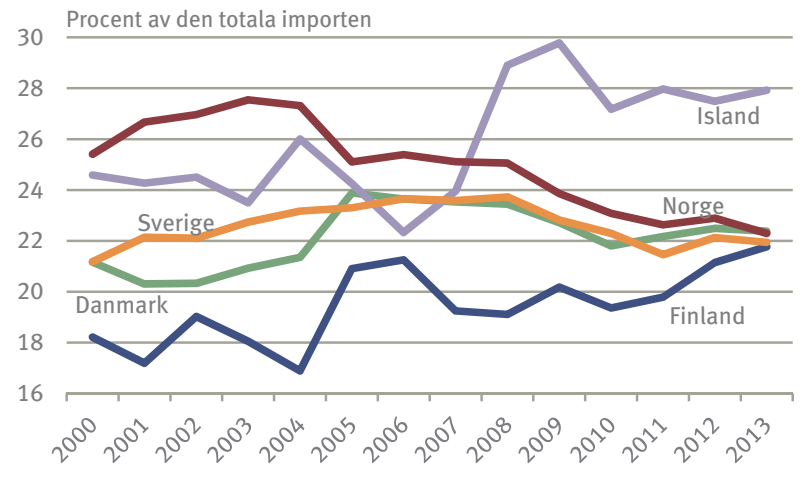

Fotr43

Visste du att ... en femtedel av utrikeshandeln i Norden är handel med de andra nordiska länderna?

(Källa: Nordisk statistik) 
stausum.

J15 Pohjola tilasto.

statistics 2015 Nordisk s

Pohjola tilastoina 2015 No

ttics 2015 Nordisk statistik 2i

ola tilastoina 2015 Nordic Stat

i Nordisk statistik 2015 Pohjol

jina 2015 Nordic Statistics :

k statistik 2015 Pohjola til

rdic Statistics $2015 \mathrm{Nr}$

115 Pohjola tilastr

- mis $\mathrm{n}$.

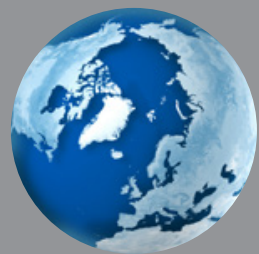

Mera statistik på www.norden.org/fakta 


\section{nordan}

Nordiska ministerrådet

Nordisk statistik 2015

Den här fickversionen innehåller bara ett litet urval ur Nordisk statistik. På www.norden.org/fakta hittar/du fler siffror och mer statistik från Norden och de nordiska länderna.

Mera statistik på

www.norden.org/fakta

ANP 2015:781

ISBN 978-92-893-4366-4 (PRINT)

ISBN 978-92-893-4367-1 (PDF)

ISSN 0908-4339 